\title{
Dickens Portrayal of the Working Class, Children and Women of Victorian Era
}

\author{
Dr.Uzma Nikhat \\ Kadirabad, Darbhanga, Bihar, India
}

DOI: $10.37648 / \mathrm{ijrssh.v10i03.046}$

Received: 27th July, 2020; Accepted: $24^{\text {th }}$ August, 2020; Published: 19th September,2020

\begin{abstract}
Charles John Haffan Dickens, the greatest English writer and novelist of the Victorian era, a social reformer and critic, who created some of the world's best-known fictional characters, is said to have enjoyed unprecedented popularity during his lifetime, (7 February 1812 - 9 June 1870) and by the 20th century. This international literary celebrity is famous for his humour, satire, keen observation of character and society portrayal of the working-class people, children and women, through his renowned works as David Copperfield, Oliver Twist Hard Times, Great Expectations, A Christmas Carol, A Tale of Two Cities, etc. Dickens' life and his literary works were interlinked. His novels and other works reflect his own life and provide a historical representation of the deplorable conditions, experienced by the poor working-class people, children and women under the oppressive power of the capitalist,

His representation of the working class describes their living conditions in English industrial towns as the highest and most unconcealed pinnacle of social misery existing in the Victorian era. He has a unique way of characterisation and his characters are realistic and true to the portrayal of class differences that existed during the 19th century.

Through his novels, he portrays the pathetic condition and brutal treatment of the unfortunate children at the work houses which is also the voice of his own self. He subtly criticizes the treatment of women by this patriarchal society where women were denied power and authority and confined to domesticity His representation of women characters is a clear portrayal of Victorian ideologies and perception towards women.

Thus, Dickens' portrayal of the working class, children and women through his novels and their characters, is a realistic depiction of the deplorable condition that attract the attention and draw the sympathy of the readers. No wonder his books are widely read even today with utmost interest.
\end{abstract}

\section{DICKENS PORTRAYAL OF THE WORKING CLASS, CHILDREN AND WOMEN OF THE VICTORIAN ERA.}

It is well said that literature is the mirror of life, an expression that explains the notion of representing society through literary texts. It is a window into the recreated realities of the writer's world. (Risdinato ,2012) All its genres deal with human experiences, but the relationship between the individual and the society is the speciality of novels.

Charles Dickens, the greatest novelist of the Victorian era, (1)a social reformer and critic, was born in Portsmouth on 7th February to John and Elizabeth Dickens. He was the second of the eight children. He lived a few years in Gotham which was soon followed by a period of intensive misery that deeply affected Dickens. He left school to work in a factory where his father was incarcerated in a debtor's prison. The strenuous and often harsh working conditions made a lasting impression on Dickens and later influenced his fictions and essays, becoming the foundation of his interest in the reform of socio-economic and labour conditions, the rigors of which he believed were unfairly borne by the poor. He later wrote that he wondered "how I could have been so easily cast away at such an age."(2). Being a victim of child labour himself and its unpleasant painful memories made him vehemently attack the unpleasant experiences and inspired much of his works notably the early chapters of David Copperfield and Oliver Twist. Dickens' life and his literary works were interlinked. His novels and other works reflect his own life. His novels provide a historical representation of the 
deplorable conditions experienced by the poor under the oppressive power of the capitalist. Most of them belong entirely to the humanitarian movement of the Victorian Age, of which they are, indeed, in the sphere of fiction, by far the most important product and expression. No doubt he was regarded as a novelist with a purpose. As a social reformer, he regarded the technology of the industrial revolution as a threat to culture. He wrote of the sycophantic rising middle class who considered wealth as a measure of worth and dreamt to become much like the frivolous aristocracy that ignored the plight of the working class and poor. Dickens felt a certain sympathy for the orphaned, the poor and those abused by the society, as he had a personal experience of it when his father was sent to the debtor's prison and he had to work at a young age. He portrays the brutal treatment of these unfortunate children at the workhouses. Indeed, his sympathies lay with such characters as Nancy of Oliver Twist, Joe Gargery and Biddy of Great Expectations, Bob Cratchit and his family, in A Christmas Carol and Mr Stephen Blackpool of Hard Times.

Through his novels, Dickens' representation of the working-class people, the children, the women are praiseworthy. He aims to attack some specific abuses existing towards children and women during the Victorian age (mid-19th century). The Victorian society consisted of a hierarchical structure, comprising the upper class followed by the middle class, the working class and the impoverished under class. These different social classes could be distinguished by inequalities in areas such as politics, authority, wealth, education, culture, working and living conditions. Members of the lower class were perceived as irrational, immature, superstitious, brutal, excessively sexual and filthy. The lower class being powerless were subjugated to exploitation similar to that of animals. Due to poverty, children were forced to live under inhuman conditions. They were made to work as chimney sweepers, where they could crawl up the 12 by 14 inches chimneys, some as small as 7 inches square, so that they would clean out the annual average of 40 gallons of soot that was deposited there. Some boys were employed as rat catchers and they were required to use arsenic to poison the rats, but as this was expensive, we could also use a ferret to flush the rats out and kill them. (3). Child labour was rampant. He expressed his anxiety and disillusionment after being exposed to child labour and the loss of an opportunity to be educated:

"No words can express the secret agony of my soul as I... felt my early hopes of growing up to be a learned and distinguished man crushed in my breast. The deep remembrance...of the

misery it was to my young heart to believe that, day by day, what

I had learned and thought, and delighted in, and raised my fancy and emulation up by, was passing away from me..cannot

be written." (qtd. by Pykett 1)

Children could also be used as messengers and it was quite common for a gentleman to ask a nearby street urchin to run petty errands for him. Dickens depicts Jo in Bleak House as a street urchin and is asked by Lady Dedlock for some information concerning Nemo. Some children worked as mud larks which meant they had to wade into the Thames River at low tide to scrounge for bits of coal, rope, bones, copper and nails.

Dickens represents the actual world through his fictional characters as Rosenberg remarks......."the best Dickens characters are examples of versimilitudinous representation."(4) Dickens characters are not only representations of the world but also reflections of the existent beings,"....... and assumed by virtually all readers to be the representation of people."(5) Therefore his child characters represent real children with actual experiences and backgrounds such as poverty, orphanage, neglect and deprivation of education. It was his unhappy period in his youth to which he alluded in his favourite and most autobiographical, novel, David Copperfield:(6)"I had no advice, no counsel, no encouragement, no consolation, no assistance, no support, of any kind, from anyone, that I can call to mind, as I hope to go to heaven!"(7) Hence his child characters are usually orphaned or their parentage is unclear, for example 'Pip and Estella'(Great Expectations), Esther (Bleak House),Oliver,(Oliver Twist) and Sissy Jupe, (Hard Times). Estella and Esther are initially introduced as orphans, but the reader later comes to know that they are actually abandoned children as is Sissy Jupe. All the three characters are adopted for example Estella is adopted by Mrs Havisham while Esther is adopted by John Jarndyce and lastly Sissy is adopted by Mr Thomas Grandgrind.

Dickens is personally aware of the exploitation to which the children are subjected because of his own history of work house incorporation which parallels Oliver's workhouse experiences. Dickens novels ultimately petition society to protect these assailed juveniles.

However, the Victorian society is paradoxical because on the one hand it viewed children as essential but on the other hand most of its juveniles were not given the chance to safely experience growth and transition into adulthood. 
As Gorham states: "........ Childhood had great symbolic importance but many Victorian suffered from an uncertainty about the nature of childhood and proper relationship of children to the structure of family and the wider society.in the late Victorian period many people were concerned about the welfare of children also found themselves uncertain about how the boundaries of childhood should be defined."(8) Most of them died in infancy or in early childhood. As far as education of these children was concerned, they received decisively less education than their middle- and upper-class peers as they had to shoulder the responsibilities at tender ages. Since schooling wasn't compulsory until 1870 , the vast majority stopped schooling if they had any as soon as they could go to work. Schooling was expensive and most working-class parents couldn't raise the fees. Gender differences also apply to the working class. Girls received even less education than boys, did more domestic chores then their brothers, worked for longer hours and less money.

Child labour was an integral part of the system as the children were far paid less than adults. They worked under terrible conditions for long hours, with poor lighting, deficient ventilation and lack of protective clothing.

Laws against child labour and the factory acts were passed in 1864 but it wasn't much effective. Unfortunately, some of these reforms were implemented long after Charles Dickens had already been forced into the gruesome and traumatising factory work at his age. Because of the parents' very restricted time resources, working-class childhoods were decisively shorter than upper- or middleclass childhood. Working class children had to contribute to their family's financial situation as early as possible mostly because of the father's poor income or for the large amount of hungry mouths to feed. There existed a sharp contrast between the living conditions of the poor and the rich. The cold grey force of property and the narrowness of circumstances were the main reasons why children were sent to work as soon as possible probably at the age of seven or even younger. As Jane Humphries puts it: "their most carefree years with those between the ages of two and three from which they could work and play and about five or six, at which point they were expected to do and to take care for younger siblings."

Even though Dickens is a male writer who conforms to the Victorian ideology of women, he strikes the readers as an author who is aware of the women's plight and their yearning for significance and belonging in a patriarchal society which abuses and marginalises them. He subtly criticises the treatment of women by this patriarchal society where women were denied power and authority and confined to domesticity. Dickens' characters like
Molly and Mrs. Joe Gargery in Great Expectations are also victims of an exploitative society.

The woman folk of the Victorian era were oppressed as they were confined to the domestic spheres for rearing children and household chores and were not welcomed in the masculine public domain of politics and business. Unlike the later feminist writers, he does not depict female characters who have economic liberty, rather yearn for financial freedom. He even breaks the Victorian ideology of women who were supposed to maintain virginity until marriage as his characters like Nancy in Oliver Twist, becomes a prostitute and has multiple sexual partners. Lady Dedlock also subverts the ideology of female purity by conceiving out of wedlock. Both characters are depictions of women in a quest for sexual freedom in a society which forces them to suppress their sexuality. In the early 19 th century, there was a high rate of prostitution, which came to be known as the great social evil. Between 1848 and 1870 there were a lot of institutions working to reclaim these fallen women from the streets and at the same time restraining them from entering the respectable society by forcing them to work as domestic servants. The theme of prostitution and the fallen women became a staple feature of the Victorian literature and politics. Sympathetic writers raised economic deprivation as a major cause of prostitution. The anonymity of the city led to the increase in prostitution and unsanctioned sexual relationship. Altick attests that "Dickens and other writers of his time associated prostitution with the mechanisation of modern life portraying prostitutes as human commodities consumed and then thrown away like refuse."(9) So the status of women in this period could often be seen as a discrepancy between England's national power and wealth and what many consider its appalling social condition. Education was considered as the economic necessity of men only. If at all women were educated, they would not receive the same as men. They were supposed to be educated in issues that involve domesticity. Women who wanted to study law, physics, engineering or medicine were satirized and dismissed. The Victorian society deemed it unnecessary for women to attend University. By analysing the character sketches of women of Great Expectations and Dickens personal life, it is very clear that Dickens is very conflicted, when it comes to the topic of women. He prefers certain kinds of women, like Biddy, who are the working class and little angels of the house and as for the other women, they are subjected to hardships and punishments for their transgressions. David Holbrook says, "when it came to the problems of men-women relationship, he was seriously hampered not only by the attitudes of his age but also by his own 
emotional makeup and psychic pattern. (10) So, Dickens in a sense is a writer who is inhibited by his personal life which narrows his views on women. Otherwise, he is a progressive writer who acknowledges the social constraints caused by society. Above all, we can say that the feminist study of Dickens female characters determines that Dickens as a male writer was sympathetic with the plight of the Victorian women. His representation of the women characters is a clear portrayal of Victorian ideologies and perceptions towards women. He explores the pathetic condition of the Victorian women and also subtly criticizes the treatment of women by the cruel patriarchal society.

Dickens' representation of the working class describes their living conditions in English industrial towns as the highest and most unconcealed pinnacle of social misery existing in their day. Dickens portrayal of the social class differences has been remarkably achieved through his characters as he has his own way of characterisation. He has a special use of characterization in which the characters seem real for the readers as T.S. Eliot remarked, "Dickens characters are real because there is no one like them" (quoted in Bloom 2004: 7). Not only can the description of coketown reveal the picture of society but also the precise description of each character. Dickens characterization in

Hard Times portrays the different social classes in an industrial town in which the three characters James Harthouse, Josiah Bounderby and Stephen Blackpool, are representatives of the upper, middle and working social class respectively. Through these characters Dickens tries to reveal the differences between the three social classes, their education, work, living conditions and even the dialects in the novel can reveal a lot about the class differences in the Victorian society (Ilhem,2012). (11)

Thus, to get a better understanding of the actual condition of the working class we need to study the conditions of the upper class and the middle class that existed in his time. Dickens upper class also called the Bourgeoisie, has been well represented by the character Mr James Harthouse in his novel, Hard Times. He is an affluent man and an aristocratic member of the society, who visited Coketown just because he becomes bored with life and is looking for something new. Dickens describes him as follows: "Now this gentleman had a younger brother of still better appearance

Than himself, who had tried life at the Coronet

Of Dragoons, and found it

a bore; and had afterwards tried it in train

of an English minister

abroad, and found it a bore; and then they
Had gone yachting about the world and got bored everywhere."(Hard Times:102). From the time of his arrival to Coke town Mr Harthouse's only goal was seducing Louisa and finding his last love. He was a young politician without heart or principles, who came to Coketown, took advantage of Louisa's unhappy life and Bounderby and attempted to seduce her. He was bored because he was from a rich family and ten hours of work to feed oneself was not his concern or a part of his regime. There is little evidence from the late 19th century to support the family picture of the bourgeois family at the light of Industrial Revolution as a secure emotional refuge from the physical and moral horrors of an encircling market economy.

Dickens' representation of the middle class has been well done through the character Mr. Josiah Bounderby of Hard Times. He goes on to personify him as --

A big loud man with a stair and a metallic laugh

A man made out of a

coarse material, a man with a great puffed head and forehead,

Swelled veins in his temples and such as trained skin to his face that it seemed to hold his eyes open and lift his eyebrows up.

a man with the prevailing appearance on him of being inflated like a balloon and ready to start. A man who could never sufficiently vaunt himself, a self-made man, a man who was always proclaiming through that brasi speaking trumpet voice of his. A man who was the bully of humility (Hard Times--16).

Mr. Bounderby leads everybody to believe that he worked hard to reach the position of a wealthy man and a factory owner and claims that each member from the middle class has worked very hard to get the owner of being where he is. In any conversation that involved his presence he spoke about his sad childhood and how his mother had abandoned him and left him to his drunken grandmother to attract people's sympathy. "I hadn't a shoe to my foot. As to a stocking, I didn't know such a thing by name. I passed the day in a ditch and the night in a pigsty. That's the way I spent my 10th birthday. (Hard Times-- 16). To the point when his mother, Mrs Pegler appears and uncovers the reality that she did not abandon him, he has no interest in helping and speaking with people whose class is lower than him as he says to Mr Jupe "we are the people who know the value of time and you are the kind of people who don't know the value of time.(HardTimes:28).He also keeps mocking and laughing at the people of circus speech. He never makes any 
consideration to other people's feelings because he always sees them as workers that can be replaced easily anytime.

Dickens' representation of the working class of the Victorian Era has been well painted by the character Mr. Stephen Blackpool of Hard Times, who is a worker in Bounderby's factory, a true representative of the working class, living a hard life with his drunken wife. Dickens describes him as a rather stooping man with a knitted brow, a pondering expression of face and hard looking head sufficiently capacious, on which his iron grey hair lay long and thin, old Stephen might have passed for a particularly intelligently intelligent man in his condition. (Hard Times:54)

He is a pessimistic but honest character, who is aware of the fact that whatever he wants is not just difficult rather impossible. He falls in love with Rachael, who is also from the same class and works at the same factory with him. Getting married to Rachael is his only dream which is something impossible just like Bounderby tells him when he asks for divorce. Stephen's dying prayer can be considered as the target message that Dickens intended to convey through Hard Times:

"In my pain an trouble, lookin up yonder-wi'it, shinin on me- I ha seen more clear, and ha made it my dying prayer that aw th ' world may on'y coom together more an get a better unnerstan'in in o' one another, than when I were in't my own weak selv (Hard Times:219).

The working class lived under pathetic poor living condition in a place full of exploitation, deprivation, desperation and oppression. Suit and ash of the factories and industries enveloped their lives and made living suffocating. With extremely low wages and long working hours their life was a virtual hell on earth, they worked from dawn to dusk as production was important to them with no regard for the rights and sufferings of the low class. The workers had no identity of their own but as machine operators and were referred to as hands. These tools of production worked in factories in appalling conditions and struggled to feed their families the two square meals of the day but ended up watching their children die in starvation or from typhus. There existed a wide gap between the rich class and the working class with a great sense of alienation that separated them like two different nations. The rich had no sympathy, no feelings for these working-class people and posed to be absolutely ignorant of their hard conditions as if they were dwellers from some different zones or some different world.

Thus, we can conclude that Dickens' representation of working-class people with special reference to children and women, through his novels, is a realistic depiction of their dull and drab conditions that existed during the 19th century. His works are social critiques which attack the institutions that do not perform the roles for which they were created and thus fail to reform society. No wonder his books are widely read even today. (12) (13)

In a nutshell we can say, "Charles Dickens is to Victorian England what Shakespeare is to Renaissance England as he was able to typify the period his writings disclose and expose. (Brown45)

\section{REFERENCES:}

\section{- $\quad$ Footnotes}

1. Black 2007, p-735

2. Forster 2006, pp- 23-24

3. Gorham, Deborah, “The 'Maiden Tribute of Modern Babylon' Re-examined: Child Prostitution and the Idea of Childhood of Late Victorian England." Victorian Studies, Vol.21:3.

4. Rosenberg, Brian. "Character and Contradiction in Dickens." Nineteenth Century Literature Vol. 47:2 (1922):148

5. Landes , David,S. The Unbound Prometheus: Technical change and Industrial Development in Western Europe from 1750 to the present. Cambridge: Cambridge University Press, 2003. 157.

6. Cain 2008, p-91

7. Wilson 1972, p-61

8. Rosenberg, Brian. "Character and Contradiction in Dickens.” Nineteenth Century Literature Vol.42:2 (1992):147

9. Buston, Antoinette (Ed). Politics and Empire in Victorian Britain: A reader. New York: Palgrave, 2001,50

10. Holbrook, D. (1993) Charles Dickens and The image of women. 1st ed.Ch-7, page-172. New York: New York University Press.

11. Ilhem,S.(2012). Cultural Outlook of Literary Dialect in Hard Times and Silas Mariner.

12. Mazzeno 2008, p-76

13. Chesterton 2005 pp- 23-24 


\section{- Works cited:}

1. Dickens, C. (1851). Great Expectations. 1st ed. [ebook] Planet PDF. Available at: http://www.planetpublish.com/wp-content/uploads/2011/11/Great_Expectations_NT.pdf [Accessed 28 Dec. 2016].

2. Holbrook, D. (1993). Charles Dickens and the image of woman. 1st ed. New York: New York University Press.

3. Wynne, D. (2010). Women and personal property in the Victorian novel. 1st ed. Farnham, Surrey, England: Ashgate Pub.

- www.google.com 